\title{
Investigating Students' Attitudes Towards Listening and Speaking in the English Classroom at Al Istiqlal University: An Action Research
}

\author{
${ }^{1}$ Khaled M S Masood, ${ }^{2}$ Hussam A Qadomi \\ ${ }^{I}$ English Department AL-Istiqlal University/ Jericho-Palestine, ${ }^{2}$ English Department AL-Istiqlal \\ University/ Jericho-Palestine
}

Email:11r.allpal@yahoo.com, ${ }^{2}$ Hussam_eteach@yahoo.com

\begin{abstract}
This study sought to investigate students' attitudes towards listening and speaking in the English classroom at Al Istiqlal University. The researchers noticed that freshmen students at Al Istiqlal University were de-motivated and reluctant to get involved in listening and speaking activities in the English classroom. One root cause may be students' prior experience of learning English in Palestinian state schools where Arabic is the dominant language (Hamdallah, 1999) and where there may be little provision of speaking and listening to English.

The researchers sought to experiment with innovative teaching methods to address these problems. These included using group work, giving students clearly defined roles, using technological applications and drawing on students' personal lives as strategies to motivate students and change their attitudes towards listening and speaking activities.

A stratified-purposeful sample consisting of 18 freshman students was selected. The researchers used a quantitative approach to measure changes. The researchers also used qualitative instrument for the purpose of the study. A questionnaire was administered at the beginning and end of the study to determine changes in students' attitudes. Also, interviews were organized to decide and get comments on the influence of the strategies which were used. Results indicated that there was a significant difference in students' attitudes towards listening and speaking activities in English class. When the researchers used different strategies such as: role plays cards, group activities, technology and different assessment forms, students expressed positive feelings, enjoyment and fun.

The researchers recommend that teachers in similar university-level context should implement different strategies such as: group wok, role plays, cards, videos and some applications i.e. Padlet to motivate students bridge the gap between school life and university life. It was also found that such strategies help to change students' attitudes to listening and speaking.
\end{abstract}

Keywords:students' attitudes, English classroom, action research

\section{INTRODUCTION}

'This is not English. I'm going to change major, I am admitted anyway?' one girl cried and burst into tears. I was not happy to hear such comments from first year students as it was the first lecture with me, especially from students who selected English major by their own. I insisted to change my students' attitude to help them love my course as it mainly depends on speaking and listening. Most of these students complained that they did not practice listening and speaking. Also, their prior experience with listening to English is very limited. Palestine state schools neglect listening and speaking parts in most of their teaching (Abu Riash, 2011). Accordingly, students' feelings towards learning English were negative. To help these students improve their listening and speaking skills, the teachers had to find ways to get them love listening and speaking. Since students' performance in class activities and skills is important for them, the first step could be arousing their interest in such activities and language skills, also helping them get rid of negative attitudes towards the activities and skills(Zoghi and Asadzadian, 2014). The 
teachers took the action of experimenting with motivational strategies adapted from Dornyei (1998) such as implementing active learning strategies: group work, giving students roles, using technology such as the Padlet application and drawing on students' personal lives so as to start changing their attitudes. No study in Palestine has investigated the freshman students' attitudes and motivation towards listening and speaking.

\section{Introduction}

Listening and speaking play an integral role in foreign /second language instruction for several reasons (Idrissovaa, Smagulovaa Tussupbekova, 2015; Rost, 1994; Underwood, 1989). Listening is vital in the language classroom because it provides input for the learner. Without understanding input at the right level, any learning simply cannot begin. Spoken language provides a means of interaction for the learner important because learners must interact to achieve understanding. Moreover, learners' failure to understand the language they hear is an impetus, not an obstacle, to interaction and learning. Exposing students to authentic spoken language presents a challenge for the learner to understand language as native speakers actually use it. In addition, listening exercises provide teachers with a means for drawing learners' attention to new forms in the language (Rost, 1994; Yildırım, and Y1ldırım, 2016). Listening skill is defined as an activity of paying attention to and trying to get meaning from something we hear. It involves understanding a speaker's accent and pronunciation, grammar, vocabulary and understanding meaning. For successful communication, listening skill is important, so it should be taught to students (Saricoban, 1999; Underwood, 1989). Listening and speaking skills in English play an essential role for the English majors (Sadiku, 2015; Gilakjani \& Sabouri, 2016; Al-Eiadeh, Al-Sobh, Al-Zoubi, Al-Zoubi, , \& Al-Khasawneh, 2016). Those skills can be fostered using role -play, language games, technology and different active learning activities.

\section{A role playing game}

A role playing game is an interactive activity or language games in which students of a language take roles of some imaginary situations that is close to real life and as a team create a story based on situation and enact the play in front of audience (classroom), for example job interview. The main aim of the role play game is to help students practice certain language functions and learn speaking skills. Role play evokes peer learning and sharing of responsibility between teacher and the learners in the teaching learning process. Students are encouraged to be involved and take part actively in the learning speaking tasks. These are some features of a good role-play: (1) It is based on a familiar situation and relevant to real world context so students can speak naturally, (2) The group of characters does not exceed 3-4 members and it takes 4-7 minutes, and (3) It fosters students ee critical thinking and creativity, and (4) It gives extensive speaking practice to all the students (Gourmelon,et al, 2011; Krish , 2001; Pravan 2008). Teachers all the time are concerned about facilitating language acquisition. Listening and speaking are suggested to be core elements of interaction facilitating language acquisition. The more students practice speaking and listening skills, the better skills they will have (Hwang \& Chen, 2013; Hwang, Shadiev \& Huang, 2011).

\section{Group work}

Many studies have examined the use of the group work, game based language learning and giving students roles strategy at the school level, but no study has involved the use of these strategies in the university level in Palestine.

When students work in group projects and collaborative learning experiences, they need to work with one another to learn the content and apply it to the task at hand (Johnson, \& Johnson, 1987; Johnson, Johnson, \& Smith, 1991; Webb, \& Palincsar, 1996). Simultaneously, learners will experience cooperation and social support (Tinto \& Pusser, 2006). Research shows that group work can have positive impacts on learners and their learning outcomes. Group work basically gives students to learn in an environment where they can explain and 'simplify 'concepts to each other. According to the learning pyramid, this reinforces the information provided by the instructor and also provides students the opportunity to learn the material from their peers, who may be able to explain it in a way that makes more sense to the other students. The concept of students working in groups also promotes a setting where cooperation produce 
better results, teaching the students valuable life-long skills that are important in the professional workplace (Laal and Ghodsi, 2012).

\section{Using Padlet}

The use of multimedia in the EFL language classroom makes the learners have a positive attitude towards learning English. The use of multimedia helps to stimulate students' interest in language learning (Nario, Santos, Castro and Balinas, 2019). Multimedia has been spread out and used by many students in their lives, but in Palestine it is not widely spread. According to Fuchs (2014), the implementation of ICT that when using technology as a means to encourage whole-class participation in classroom activities, there are benefits and risks to consider. First, among the benefits is the idea of technology offers equal opportunity, particularly when the participant has the option to be anonymous. If students are not confident in their ideas or not sure if they have the right answer, any chance of failure is minimized when no one knows what answer they typed. This realization can allow more freedom and experimentation in the learning process. In addition, students are drawn to the novelty of the technology and seem to want to participate just to have the opportunity to use it. A final benefit of real time participatory technology is that it can give the teachers a more complete picture of learning from all students, rather than from a handful of the most confident ones. The teacher can implement that information to inform lesson development, creating a more targeted and authentic interaction between the teacher and the students.

Padlet is a [virtual] space where the admin can add files, links, videos, and more. By using this, tutor can create various walls to add your favorite content. Tutor/teacher may develop the above wall to collect and share a few of his favorite technology resources. People can also collaborate to continue adding to the same wall space. By using this, it can create a live discussion among the tutor and students and also co-tutors (Klein, 2013).

Lestari and Kurniawan (2018) in their study aimed to know whether the use of Padlet as media can improve students' descriptive writing mastery of students of English Department of Uniska in the third semester. The research design used is consisting of two cycles. Each cycles consisted of three opportunities for students to have interaction using Padlet. The cycle consisted of planning, implementing, observing and reflecting. The instruments used in this research were observation check list and writing test using Padlet. Padlet was introduced from the first time of teaching learning process in the class and the following interactions were using Padlet without having direct interaction in the classroom. The first cycle was not successful because of the students got difficulty in managing time in accessing Padlet and some errors in their grammatical used. Then in the second cycle, the result showed that 18 from 20 students passed the minimum score and all students did all assignment using Padlet. From the result, it can be concluded that the implementation of Padlet as media can improve students' writing mastery.

Many studies (Handayani, 2013; Vogel et al. 2006; Young et al. 2012) have reviewed role play and Game- Based language learning as active learning strategies that have been shown to help improve learners' engagement, conversation, communicative skills and adds more humour to the English class (Lombardi, 2012).

In this study, one main question is investigated:

What are the students' attitudes towards English language listening and speaking on pre- and post measures?

\section{Implementation}

"Teacher can I bring some vocabulary and ask Mr. Robert to tell us how they use them in the UK?" "I love your class." "Where is Mr. Robert!'. "This is our favourite class." 'We notice that our speaking and listening are getting much better! " These are just a few comments that I heard from students while using group work, game based language learning and giving them roles as parts of the daily curriculum instructions. I observed as the attitudes of my students improved throughout the semester compared with the beginning. To be able to measure the influence of our strategies, we began a study in the winter semester and recorded data during a 8-week implementation of game based language learning and giving them. Documenting student progress was important not only for the researchers, but also for 
sharing with the department what we were doing in our classroom to effectively change students attitudes to become positive. Before beginning the implementation of group work, game based language learning and giving them roles with our students, we used pre- questionnaire to identify students' attitudes. Then we chose several group work activities and in every class, we used role cards and language games. The first was Introductions and Personal information. Every time we urged the class to use English even while chatting with their group members. In addition to going over the groups to check answers, some students asked for help.

We planned a routine for a typical week. Every Saturday, each student recalled on his/her personal life. Using games, we pre-taught specific vocabulary words before students begin with the listening part. On this day, 15 minutes of each class period was spent reviewing vocabulary. Students had time to listen and decide on their roles (reporter, timekeeper, note taker and chairperson). The second class, students chose their roles speaking. Some of the students would try to imitate the way native speakers do when they were exposed to the listening part. They imitated to make their part in speaking more interesting. Some of the students would try to use British accent to make their part more fun. 'Role play cards give us a good chance to decide, interact, fun and speak' this comment came from a student who initiated activities.

Several students would ask questions about the new vocabulary they collect in the weekend. I would facilitate the topics by giving students background information on the lesson to help them understand the listening and speaking tasks they will have. On the third lecture, students watched YouTube short clips. I integrated YouTube that aligned with their lesson that week. This YouTube motivated students and provided them a way to understand the components easily. Some students commented saying 'I learned new vocabulary and pronunciation from YouTube' and 'I liked YouTube because this activity helps us to improve our language and it was fun'.

Students' attitudes and feelings as well as their motivational orientations towards learning the language are affected by the way language teachers test their learners (Al-Jamal and Ghadi, 2008). Concerning assessment, assignments usually were only once a week using Padlet application. Students recorded their speaking assignments and sent them on Padlet. This component was included as a way for students to express their understanding of the speaking assignments in a different way and was done by the students. Self and peer assessment were used as alternative assessment tools for the traditional quizzes and summative tests. Students enjoyed this type of assessment. 'Every time I assessed my classmate, I felt enjoyment.' One student comments. On the fourth lecture, students again listened and spoke using all the above mentioned strategies a class. This repeated listening and speaking strategy provided students opportunities to improve in both skills.

\section{Methodology}

The researcher used mixed research approach including qualitative and quantitative methods.

Participants

A stratified -purposeful sample consisted of 17 freshman students was selected to participate in this action research.

Instrumentation

The researchers used qualitative and quantitative tools including questionnaires, interviews and observation. The questionnaire was based on research studies conducted by Viet's (2017) which focused on students' attitudes towards students learning of English.

Questionnaire surveys were administered to collect data from the sampled students. Details of the sample are shown in Table 1.

Table 1. Details about the sample and population

\begin{tabular}{lll}
$\#$ & Description & Number of students \\
\hline $\mathbf{1}$ & Population & 1300 \\
$\mathbf{2}$ & Sample & 18 \\
$\mathbf{3}$ & Number of returned questionnaires & 17 \\
\hline
\end{tabular}

Validity

Table 2. Results of Person correlation.

\begin{tabular}{|l|l|l|l|}
\hline No & Item & $\begin{array}{l}\text { Pearson } \\
\text { correlation }\end{array}$ & Sig. \\
\hline
\end{tabular}




\begin{tabular}{|l|l|l|l|}
\hline 1. & You like to use English every day. & $.74^{* *} 0$ & 0.000 \\
\hline 2. & You like someone else speaking with you in English & $.62^{* * *} 0$ & 0.000 \\
\hline 3. & You like to speak English & $.70^{* *} 0$ & 0.000 \\
\hline 4. & You like to read books, documents and journals in English & $.01^{* * *} 0$ & 0.000 \\
\hline 5. & You like watching videos in English & $.63^{* *} 0$ & 0.000 \\
\hline 6. & $\begin{array}{l}\text { In general, you realize that learning English is important and you love } \\
\text { learning English }\end{array}$ & $.80^{* * *} 0$ & 0.000 \\
\hline 7. & You spend a lot of time learning English & $.69^{* *} 0$ & 0.000 \\
\hline 8. & $\begin{array}{l}\text { You will enroll an extra English course even if it is not a compulsory subject } \\
\text { in the school }\end{array}$ & $.70^{* * *} 0$ & 0.000 \\
\hline 9. & $\begin{array}{l}\text { Being able to communicate with foreigners in English is a fundamental } \\
\text { purpose of learning English. }\end{array}$ & $.53^{* * *} 0$ & 0.000 \\
\hline 10. & Being able to speak English is an advantage in the present time & $.77^{* *} 0$ & 0.000 \\
\hline 11. & You need English to be more successful in your studies & $.69^{* * *} 0$ & 0.000 \\
\hline 12. & English is an important tool in scientific research & $.61^{* * *} 0$ & 0.000 \\
\hline 13. & All students should learn English & $.77^{* *} 0$ & 0.000 \\
\hline 14. & $\begin{array}{l}\text { Learning English is important to you, because English is a very useful tool in } \\
\text { modern society }\end{array}$ & $.69^{* * *} 0$ & 0.000 \\
\hline 15. & When someone speaks English, you think they make a good impression & $.84^{* *} 0$ & 0.000 \\
\hline 16. & Learning English will help to develop your mind. & $.56^{* *} 0$ & 0.000 \\
\hline 17. & Students should regularly use English in communication & $.74^{* *} 0$ & 0.000 \\
\hline 18. & When someone speaks English you think they are good and qualified & $.73^{* *} 0$ & 0.000 \\
\hline 19. & $\begin{array}{l}\text { The important purpose of learning English is to get high score in English } \\
\text { Tests }\end{array}$ & $.82^{* * *} 0$ & 0.000 \\
\hline 20. & The important goal for learning English is to get a college degree & $.79^{* *} 0$ & 0.000 \\
\hline 21. & The important purpose of learning English is to have a good job & $.74^{* *} 0$ & 0.000 \\
\hline
\end{tabular}

As table 3 indicates, the Cronbach's alpha reliability coefficient for the questionnaire is 0.95 . This shows that the reliability is high and the instrument suits the purposes of the study.

\section{Results related to the research question:}

This action research tried to answer the following research question: What are the students' attitudes towards English language listening and speaking on pre- and post measures?

The researchers tried to answer the question using both qualitative and quantitative data.

\subsection{Quantitative data analysis and findings:}

Paired-Sample T-Test was used to measure the difference between pre and post measures. To identify if there was a difference between both measures, means of pre and post measures was estimated as it is clear in table 4.

Table 4. Results of Paired- Sample T-Test and significance of the difference between means on both pre and post tests $(\mathrm{n}=17)$.

\begin{tabular}{|l|l|r|l|l|l|l|}
\hline Variable & Measure & Means & SDs & T-value & Significance & Level \\
\hline Total $\begin{array}{l}\text { score of } \\
\text { score } \\
\text { attitudes }\end{array}$ & Pre & 2.68 & 0.18 & \multirow{2}{*}{$-4.67^{* *}$} & 0.000 & Significant \\
\cline { 1 - 4 } & Post & 3.29 & 0.59 & & & \\
\hline
\end{tabular}

$\mathrm{T}$ value at $(0.05)=2.12$, $\mathrm{T}$ value at $(0.01)=2.92$.

It is pretty obvious from table 4 above that the estimated $\mathrm{T}$ value is greater than the tabulated $\mathrm{T}$ value at $(0.05)$ and the total score. This shows that there are statistically significant differences between both measures (pre and post measures) of English language students' attitudes towards learning listening and speaking skills in favour of post measure. Table 4 above reveals that the pre-measure mean is 2.68 and the post measure is 3.29 , this indicates that English language students attitudes towards listening and 
speaking skills has noticeably changed compared with their attitudes at the beginning of the course. This leads to a very interesting and important conclusion that the strategies English language teachers used with students during the semester in teaching the skills of listening and speaking are important. This is because the freshmen students in a way such strategies change their attitudes towards learning English in general and listening and speaking skills in specific.

\subsection{Qualitative data analysis and findings:}

Only18 students were enrolled in the course. We asked the Department of languages permission to allow us to distribute the questionnaire get feedback and organise interviews with the students. Also, we asked the Department to use students' data in our article. We recorded data from students asking them to give us feedback, express their feelings and attitudes towards activities and methods of assessment we used. We administered the questions to the 17 students who participated in the study including activities and changing the assessment method, we measured students speaking and listening using Assessing Speaking Performance Cambridge English of A2 level.

The qualitative data were obtained from students' feedback and group interviews. The feedback strips were given to students in English at the end of each activity to write things they enjoyed about the activities and things they felt could be improved. Results indicated that students enjoyed role play in English without using Arabic which is their mother tongue with peers and role cards when used in groups. Such results could be opposite to (Alenezi and Kebble, 2018) where they examined Saudi medical students attitudes towards English -Arabic code switching. When asked about the Padlet, students indicated that active involvement in recording and getting feedback in English made speaking more enjoyable and interesting. Most of the students said 'we learn more vocabulary and more things and how I can pronounce sentences'. Several students commented that they liked the speaking activities in this way some students said 'We learn new meaning and we improve our old information; it's a new experience for us'. For example, while role playing job interview, students commented that they understood how to act the roles of employer and applicant and how to form questions using vocabulary given to them better compared with the first class where students were seated in a traditional way. Students suggested including more exercises. ' I think it's good; you should continue this activity' some students said.

Regarding group interviews, students produced the same types of comments. In addition, students commented that they enjoyed the variety of activities in english and liked the video observation part. Some students said ' these activities are fantastic ideas you got out of the routine.' others said 'the speaking activities take me a chance for speaking so it's a good idea'. The results of the data analysis reported in this action research are consistent across both qualitative and quantitative measures. During the group interviews, several participants commented on how these different strategies of assessment, speaking activities (role plays, group work, padlet, motivational activities ...) Have influenced them ' $\mathrm{i}$ enjoyed this way of assessment'. Several students also suggested that it would be more fun to use english language via padlet more frequently as it is fun, involve them and new experience for them ' $i$ feel involved and enjoy using english and out of routine when i record and send on padlet " and "a chance to speak".

\section{CONCLUSION}

The results from data collected throughout this research study showed that group wok, role plays cards, videos and some applications i.e. Pallet to motivate students, bridge the gap between school life and university life changed students' attitudes and motivated the students in the listening and speaking classroom. Through pre-measure mean is 2.68 and the post measure is 3.29, this indicates that English language students attitudes towards listening and speaking skills has noticeably changed compared with their attitudes at the beginning of the course. Even though we did not have a control group, this study illustrated that using different activities is a viable method for changing students' attitudes towards learning EFL and increasing their motivation. I encourage all teachers to use group wok, role plays cards, videos and some applications i.e. Pallet to change freshmen students attitudes they carry with them from schools and motivate them in their own classrooms. The researchers recommend that teachers in similar university-level context should implement bridge the gap between school life and university life. It was found that helps to change students' attitudes to listening and speaking. 


\section{REFERENCES}

1. Alenezi , M.Q. and Kebble, G., P.(2018). Investigating Saudi medical students' attitudes towards English-Arabic code-switching in classroom instruction. The Asian ESP Journal, 14 (1): 142-161.

2. -Al-Eiadeh, A..R, Al-Sobh, Al-Zoubi,M.A, Al-Zoubi, S.M, \& Al-Khasawneh, F. (2016). Improving English Language Speaking Skills of Ajloun National University Students. Jordan :Ajloun National University. 5 (3). Retrieved on 21st of September, 2019 from https://www.researchgate.net/publication/306079718_Improving_English_

Language_Speaking_Skills_of_Ajloun_National_University_Students.

3. -Al-Jamal, D. and Ghadi, N.(2008). English language General Secondary Certificate Examination washback in Jordan. The Asian EFL Journal,10(3): 158-186.

4. -Banegas, D. (2013). Teacher Professional Development through Collaborative Action Research: Impact on Foreign English-Language Teaching and Learning. Routledge.

5. -Banegas, D., Pavese, A., Velázquez, A., \& Vélez, S. M. (2013). Teacher professional development through collaborative action research: impact on foreign English-language teaching and learning. Educational Action Research, 21(2), 185-201.

6. -Bhasin, M.(2011). Classification of Flames in Computer Mediated Communications. International Journal of Computer Applications, 14(6), 21-26.

7. -Burns, A. (2019). Doing action research in English language teaching: A guide for practitioners. Routledge.

8. -Burns. A. and Westmacott, A. (2018). Teacher to researcher: Reflections on a new action research program for university EFL teachers. Retrieved online from:

9. - Edgar, G.\& Randall, B.(2014). The impact of a first year development course on student success in a community college: An empirical investigation. American Journal of Educational Research, 2 (6), pp 402-419. DOI: 10.12691/education-2-6-13.

10. - Gourmelon,F., Rouan M., Lefevre, J. and Rognant A.(2011). Role-Playing Game and learning for young people about sustainable development stakes: An experiment in transferring and adapting interdisciplinary scientific knowledge. Journal of Artificial Societies and Social Simulation 14 (4) 21.

11. -Hamdallah, R. (1999). To use or not to use Arabic in English language teaching. An-Najah University Journal for Research, 13(1): 285-296.

12. -Handayani, L. (2013). Promoting students' speaking ability through role play within discourse based approach. Journal Social Humaniora. 6. 10.12962/j24433527.v6i1.612.

13. -Hwang, W.Y., \& Chen, H.S. (2013). Users' familiar situational contexts facilitate the practice of EFL in elementary schools with mobile devices. Computer Assisted Language Learning, 26(2), 101-125. 